\title{
Influence of Recreational Facilities among Adolescents towards Leisure Time Physical Activity (LTPA)
}

\author{
Rozita Abd-Latif ${ }^{1}$, Maizan Mohd Nor ${ }^{1}$, Mohd Sofian Omar-Fauzee ${ }^{2}$, \\ Abdul Razak Ahmad ${ }^{3}$ \\ ${ }^{1}$ Sports Science and RecreationFaculty, Universiti Teknologi MARA \\ ${ }^{2}$ Sports Academy, Universiti Putra Malaysia \\ ${ }^{3}$ Education Faculty, Universiti Kebangsaan Malaysia \\ rozita.abdlatif@salam.uim.edu.my
}

\begin{abstract}
The purpose of this study is to identify the influence of recreational facilities towards leisure physical activities among youth. As many as 913 respondents aged between 13 to 17 years old from four districts (Seremban, Muar, Kota Star and Kuantan) in Peninsular Malaysia, were chosen through a layered cluster random sampling technique. The results show that the safety of the environment is in moderate level (busy road: $M=3.51, S P=1.31$; stray dog: $M=3.46, S P=1.38$; crime: $M=3.23$, $\mathrm{SP}=1.33)$ and it has no connection with the involvement of youths in LTPA $(r=-0.01, p>0.05)$. It is also discovered that sports facilities limit them from undergoing physical activities during leisure hours. However, facilities are easy to be used $(75 \%)$ by youths and this leads to a significant relationship with LTPA $(r=0.10, p<0.05)$. The implication of this research shows that physical environment is pivotal in order to increase the level of youth involvement in overall free time physical activities. Thus, it is suggested that these physical activities can only take more of the teenagers' time if they are carried out in environments which are creative, comfortable, safe and user-friendly.
\end{abstract}

Keywords: physiccal activity, physical environment, and adolescents.

eISSN 2514-751X@ 2017 The Authors. Published for AMER ABRA by e-International Publishing House, Ltd., UK. This is an open access article under the CC BY-NC-ND license (http://creativecommons.org/licenses/by-ncnd/4.0). Peer-review under responsibility of AMER (Association of Malaysian Environment-Behaviour Researchers), ABRA (Association of Behavioural Researchers on Asians) and cE-Bs (Centre for EnvironmentBehaviour Studies), Faculty of Architecture, Planning \& Surveying, Universiti Teknologi MARA, Malaysia. https://doi.org/10.21834/aje-bs.v2i4.211 


\subsection{Introduction}

Physical activity is a form of behavior whose type, frequency, duration and intensity depend on individual preference. (Luke, Philpott, Brett, Cruz, et al., 2004). According to Basrur (2003), physical activity is any movement that involves energy consumption. It can be either structured (for example: fitness classes), non-structured (for example: collecting golf balls), planned (for example: slow jog) or unplanned (for example: climbing stairs).

The environment, in a way, influences adolescents' behavior. It has been stated earlier that the physical environment consists of authentic and shaped environments (Sallis \& Owen, 1997), that include recreational infrastructure, transportation and public situations such as safety, natural environment such as the location and weather as well as facilities and equipment (Davison \& Lawson, 2006; Poulsen \& Ziviani, 2004). In this study context, physical environment refers to safety of the environment and sport and recreational facilities that are provided by school, district or local council and private sports organizations that can be used by the community. These are located within a five-kilometer radius or 30 minutes traveling from their homes.

Individuals who are active are those who often receive strong support from their social and physical environments. Giles-Corti and Donovan (2002) and Utter (2001) have identified that the active participation of adults in vigorous activities is contributed by the use of at least one sport facility in the vicinity of their homes especially in registered sports clubs situated between the range of 1:40 mile from their residential areas. Moreover, active use of sports facilities is dependent on the pattern of the environmental development (Sallis et al., 1998) which is free from bureaucracy procedure, alongside the fact that they are comfortable, safe and attractive (King, Jeffery, Fridenger, Dusenbury, Provence, et al., 1995). Thus, Veitch et al. (2006) advised that parents should not worry too much about their children's potential and the level of safety in the surroundings in order to enable them to move around in the playground area without assistance.

\subsection{Literature Review}

The launching of MALAYSIA CERGAS in 1983 was intended to give emphasis to the efforts of expanding sports and recreational activities in order to encourage more Malaysian participation to improve the quality of life and health (Malaysia Cergas, KKBS, 1983). Accordingly, the government increased the allocation for KBS from RM227.5 million in 2002 to RM657.9 million in 2003 to provide a wide range of activities and facilities as well as to encourage Malaysians to be more actively involved. In the 9th Malaysia Plan, the government had also allocated a sum of money to build 13 community sports complexes to promote community participation in sport activities, exercise and recreation (Dato' Seri Abdullah, 2006). On the other hand, the Ministry of Housing and Local Government had also directed that 10 percent of new residential areas should be used to provide open spaces, playgrounds or parks to be utilized by local residents to carry out physical activities 
(www.townplan.gov.my). With the community sports complexes and local facilities provided, residents have the opportunity to do sports, exercises and recreation at any preferred time.

The effectiveness of physical activities on one's health depends on practice. The International Consensus Conference on Physical activity Guideline for Adolescents suggests that teenagers carry out physical activities on a daily basis or almost everyday (Sallis \& Patrick, 1994). Based on previous studies, physical activity and health promotion have shifted from changing individual knowledge, attitudes and skills to influencing and changing the social and physical environment (Phongsavan, Mclean, \& Bauman, 2007).

Sallis and Owen (1997) believe that the physical environment consists of the authentic environment and shaped environment like (i) safety, (ii) natural environment such as weather, (iii) location and (iv) facilities and equipment (Poulsen \& Ziviani, 2004). However, the ratio of sports facilities provided by local authorities is inadequate for the total population of an area (Zaini Arshad, 2003; National Sports Council, 1992). Thus, Giles-Corti \& Donovan (2002) state that research on facilities should be given the priority in supporting youth participation in physical activities. Therefore, the purpose of this study is to identify the influence of physical environment on leisure physical activity among adolescents.

\subsection{Methodology}

Cluster sampling or multistage sampling is used to identify the area of research which involves several divisions and groups where the respondents come from (Seremban, Muar, Kota Star, Kuantan) in Peninsular Malaysia. This method involves the sample from selected level (Kevin, 1993). There are around 913 adolescents involved in this study, $48.5 \%$ males and $51.5 \%$ females. In terms of age group, 165 (18.1\%) are 13 years old and $222(24.3 \%)$ are 14 years old. On the other hand, adolescents aged 15, 16, and 17 represent the mid-teenage group. The highest percentage of respondents are $210(23 \%)$ represented by the16 year-old group, followed by $164(18 \%)$ from the 15 year-old group and lastly $152(16.6 \%)$ of the 17 year-old group. In terms of SES, 402 adolescents (44.0\%) are from medium SES's family background, 265 (29.0\%) from higher SES background and only $246(26.9 \%)$ from the lower SES background.

This research uses a quantitative design carried out as a survey study and comprises two categories of data collection. The questionnaires have been modifed from "The Awareness of Facilities" (Sylvia-Bobiak \& Caldwell 2006), whereby respondents will be asked about the facilities related to physical activities available in their vicinity. If the respondent answers 'yes', he or she will proceed to answer the next Likert 4 scale question in which $1=$ very hard, $2=$ hard, $3=$ easy dan $4=$ very easy. 


\subsection{Results And Discussions}

Based on the frequency of physical activities' involvement in Table 4.0, it is evident that 418 (45.8\%) adolescents are not involved in physical activities. Meanwhile, 359 (39.3\%) adolescents are not actively involved. The data also show that only 136 adolescents are actively involved in which $27.7 \%$ of them perform medium physical activities five times a week and $71.3 \%$ adolescents perform vigorous activities at least 3 times a week.

Table 4.0: Level of involvement of the adolescents in physical activities

\begin{tabular}{|l|c|c|}
\hline \multicolumn{1}{|c|}{ Source } & Frequency (n) & Percentage (\%) \\
\hline Frequency (METs- 7 day/week) & & \\
- Not involved in physical actity & 418 & 45.8 \\
- Involved but not active & 359 & 39.3 \\
- Active 1 & 39 & 4.3 \\
- Active 2 & 97 & 10.6 \\
\hline
\end{tabular}

Table 4.1: Level of sports/recreational facility usage among adolescents

\begin{tabular}{|c|c|c|c|c|c|}
\hline \multirow{2}{*}{$\begin{array}{l}\text { Sports } \\
\text { Facility }\end{array}$} & \multicolumn{4}{|c|}{ Facility Usage } & \multirow{2}{*}{$\begin{array}{r}\text { Total of } \\
\text { facilities } \\
\text { distribution }\end{array}$} \\
\hline & Very easy & Easy & Hard & Very Hard & \\
\hline Football & $\begin{array}{c}247 \\
(27.1 \%)\end{array}$ & $\begin{array}{c}305 \\
(33.4 \%)\end{array}$ & $\begin{array}{c}74 \\
(8.1 \%)\end{array}$ & $\begin{array}{c}39 \\
(3.9 \%)\end{array}$ & 862 \\
\hline $\begin{array}{l}\text { Sepak } \\
\text { takraw }\end{array}$ & $\begin{array}{c}149 \\
(16.3 \%)\end{array}$ & $\begin{array}{c}244 \\
(26.7 \%)\end{array}$ & $\begin{array}{c}73 \\
(8.0 \%)\end{array}$ & $\begin{array}{c}44 \\
(4.8 \%)\end{array}$ & 510 \\
\hline $\begin{array}{l}\text { Jogging } \\
\text { track }\end{array}$ & $\begin{array}{c}136 \\
(14.9 \%)\end{array}$ & $\begin{array}{c}153 \\
(18.8 \%)\end{array}$ & $\begin{array}{c}20 \\
(2.2 \%)\end{array}$ & $\begin{array}{c}24 \\
(2.6 \%)\end{array}$ & 333 \\
\hline Netball & $\begin{array}{c}25 \\
(27.3 \%)\end{array}$ & $\begin{array}{c}125 \\
(13.8 \%)\end{array}$ & $\begin{array}{c}80 \\
(8.7 \%)\end{array}$ & $\begin{array}{c}83 \\
(6.9 \%)\end{array}$ & 293 \\
\hline Basketball & $\begin{array}{c}67 \\
(7.3 \%)\end{array}$ & $\begin{array}{c}128 \\
(14.0 \%)\end{array}$ & $\begin{array}{c}48 \\
(5.3 \%)\end{array}$ & $\begin{array}{c}27 \\
(3.0 \%)\end{array}$ & 270 \\
\hline Volleyball & $\begin{array}{c}66 \\
(7.2 \%)\end{array}$ & $\begin{array}{c}124 \\
(13.6 \%)\end{array}$ & $\begin{array}{c}53 \\
(5.8 \%)\end{array}$ & $\begin{array}{c}24 \\
(2.6 \%)\end{array}$ & 267 \\
\hline $\begin{array}{c}\text { Sports } \\
\text { Complex }\end{array}$ & $\begin{array}{c}82 \\
(8.8 \%)\end{array}$ & $\begin{array}{c}85 \\
(9.3 \%)\end{array}$ & $\begin{array}{c}32 \\
(3.5 \%)\end{array}$ & $\begin{array}{c}30 \\
(3.3 \%)\end{array}$ & 200 \\
\hline $\begin{array}{l}\text { Swimming } \\
\text { Pool }\end{array}$ & $\begin{array}{c}15 \\
(1.6 \%)\end{array}$ & $\begin{array}{c}35 \\
(3.8 \%)\end{array}$ & $\begin{array}{c}21 \\
(2.3 \%)\end{array}$ & $\begin{array}{c}27 \\
(3.0 \%)\end{array}$ & 98 \\
\hline Tennis & $\begin{array}{c}20 \\
(2.2 \%)\end{array}$ & $\begin{array}{c}33 \\
(3.6 \%)\end{array}$ & $\begin{array}{c}28 \\
(3.1 \%)\end{array}$ & $\begin{array}{c}12 \\
(1.3 \%)\end{array}$ & 93 \\
\hline \multicolumn{2}{|c|}{$x^{2}=702.750$} & \multicolumn{2}{|c|}{$\mathrm{DK}=27$} & \multicolumn{2}{|c|}{$P=.000$} \\
\hline
\end{tabular}

Table 4.1 shows that $247(27.1 \%)$ of adolescents agree that it is very easy to use the sports facilities and $305(33.4 \%)$ of them state that it is easy to use the sports facilities. Out 
of 662 respondents, $113(12 \%)$ adolescents have made claims that there are a lot of procedures needed in order to use the football field in their neighbourhood. Meanwhile, 117 $(12.8 \%)$ adolescents complain that it is hard for them to get access to the sepak takraw court while on the contrary, 393 (43\%) state that it is easy for them to use the sepak takraw court.

According to 333 adolescents on the jogging track available in their area, 289 of them state that they can use the track easily compared to 44 adolescents who claim that it is hard for them to use a jogging track. For netball, 150 adolescents state that it is easy to use the facility while 143 of these youngsters state otherwise. In the meantime, 270 adolescents acknowledge that there is a basketball court provided, but only 195 of them respond that it can be used easily compared to 75 who claim it is not easy to use the court. $194(20.8 \%)$ adolescents also claim that it is easy to use the volleyball court compared to 77 respondents who claim the opposite. Finally, 53 adolescents convince us that it is easy to use the tennis court and 40 of them elaborate in a different direction by saying that there are a lot of procedures that need to be undergone in order to use the tennis court. When this sample variation is viewed based on the chi-square analysis, it explains that there is a significant relationship $(X 2=702.750, p=.000)$ between the facility usage and the physical activity variables

Based on Table 4.2, the mean and standard deviation show that the question items are in moderate level in which the respondents' residential areas are safe with low rates of crime $(M=3.51, S D=1.30)$, fewer stray dogs $(M=3.46, S D=1.38)$ followed by the location of sports facility which is not close to any busy roads $(M=3.23, S D=1.32)$. In brief, the respondents' perceptions of the safety level in their areas have been positive. Besides, the safety level has a significant relationship if it is analysed based on the small standard deviation difference.

Table 4.2: Distribution of mean and common deviation safety item

\begin{tabular}{|l|c|c|c|}
\hline \multicolumn{1}{|c|}{ Item } & Mean & Standard deviation & Explanation \\
\hline $\begin{array}{l}\text { Sports facility is located near } \\
\text { busy road. }\end{array}$ & 3.234 & 1.32 & Moderate \\
\hline $\begin{array}{l}\text { Rates of crimes are high in my } \\
\text { residential area. }\end{array}$ & 3.515 & 1.30 & High \\
\hline $\begin{array}{l}\text { Stray dogs often seen around } \\
\text { sports activities' areas. }\end{array}$ & 3.456 & 1.38 & Moderate \\
\hline Safety & 3.402 & 1.05 & Moderate \\
\hline & $\mathrm{X}^{2}=201.141$ & $\mathrm{DK}=27$ & $\mathrm{P}=.000$ \\
\hline
\end{tabular}

The Pearson $r$ correlation test in Table 4.3 shows that there is a significant but poor relationship that can be omitted between the facility support and usage level in the involvement of the physical activities. The analysis' result shows facility $(r=.069, p<0.05)$ 
and usage level $(r=.094, p<.05)$ to have significant relationship in influencing adolescents' involvement in physical activities. Meanwhile, in safety aspects, it only affects selfefficacy and not the physical activities themselves.

Table 4.3: Relationship between the facility support and usage level of physical activities' involvement

\begin{tabular}{|c|c|c|}
\hline \multirow{2}{*}{} & \multicolumn{2}{|c|}{ physical activity involvement } \\
\cline { 2 - 3 } & $\mathbf{r}$ & $\mathbf{p}$ \\
\hline Usage level & $.094^{x}$ & .004 \\
\hline Facility & $.089^{x}$ & .038 \\
\hline Safety & .002 & .951 \\
\hline
\end{tabular}

significant level $p<0.05$

\subsection{Discussion}

There are 913 adolescents involved in this study, of which $48.5 \%$ are male and $51.5 \%$ female. The result has shown that $418(45.8 \%)$ adolescents are not involved in physical activities. Meanwhile, 359 (39.3\%) adolescents are not actively involved in physical activities. Age is also an important factor that influences their involvement in LTPA. The data shows a difference between different age groups of adolescents.

This study shows that inactive respondents are between the age group of 15 to 17. One possible reason may be due to the fact that striving for good academic achievement is the main focus for this age group (Editorial, 2005; Wu \& Jwo, 2005; Janaun, 1992). School administrators and teachers can also be one of the factors by looking down on physical activity including physical education and health (PJPK) classes and co-curriculum activities (Seligman, 1995) although it can affect social skills development. Nevertheless, most of the findings show that there is an inverse relationship between age and involvement in these activities. In general, it can be said that there are many factors that contribute to an active lifestyle. It can be physiological, psychological, socio-cultural or environmental (Caspersen, Pereira \& Curran, 2000; Khol \& Hobbs, 1997; Sallis et al., 2000). Individuals who are active are those who often receive support from their social and physical environments (Giles-Corti \& Donovan, 2002). Most adolescents agree that there are popular sports facilities like jogging, soccer, basketball, takraw and netball provided in their areas. Most youths love to use sports facilities that are near their homes that incur no charges on them. The result shows a significant relationship $(X 2=702,750, p=0.000)$ between the variable of the use of facilities and physical activity behaviour.

These findings show that the adolescents consider their residential areas to be secure since the crime activity is low $(M=3: 51, S D=1.30)$, stray dogs are scarce $(M=3: 46, S D=$ 1.38 ) and sports facilities are located in less busy roads ( $M=3.23, S D=1.32)$. Thus, this indicates that the adolescents have good evaluations of the level of security in the area. Meanwhile, the safety levels of the neighbourhood and recreation area are also in good 
condition ( $X 2=201,141, p=.000)$ and this affects these youngsters' behavior in the physical activities. Research by Gordon-Larsen et al. (2000) and Humpel et al. (2004) also discover that active adolescents are those who consider their physical environments to be safe. Previous research findings show that parents are concerned with the safety level and if their children are able to perform activities alone or in groups in recreational areas (Veitch et al., 2006).

This research shows that there is a relationship between physical environmental factors and physical activites despite the fact that it is less important and can be abandoned. There are several possible reasons for this. The first is related to the respondents' wrong interpretation of the definition "ease of use of sports facilities". The definition of "ease of use" actually depends on how active the adolescents are in performing these physical activities. For an adolescent who often engages in physical activities, "ease of use" would be very easily understood while for first timers the interpretation may vary. Thus, every individual's interpretation of the phrase "ease of use" do affect the research findings.

Secondly, the existence of such a relationship may boil down to too many sports facilities. Fields and courts are multi-purpose facilities than can actually be utilized for different types of sports. For instance, a football field can be used to hold netball or softball games. This causes sports facilities to be limited and therefore, the extent of accessibility and "ease of use" are also automatically limited

\subsection{Conclusions}

In conclusion, the relationship between peers, parents, school, safety, and sports facilities as well as the level of usage do affect the adolescents' involvement in physical activities even though the relationship is weak. The support from school and the physical environment also affect their behaviour although this has not been very apparent in these adolescents. This shows that social support and the physical environment are not the main factors for adolescents to be active. However, physiological and sociological changes are the factors that cause the decline of involvement in physical activities among adolescents.

\section{Acknowledgements}

Thank you Universiti Teknologi MARA for giving me the scholarship to further my studies at UKM, A.P. Dr. Mohd Sofian, thank you for your ideas.

\section{References}

Aaron, D.J., Storti, K.L., Robertson, R.J., Kriska, AM., \& LaPorte, RE. (2002). Longitudinal study ofthe number and choice of leisure time physical activities from mid to late adolescence. Archive pediatric adolescence medical, 156, 1075-1080. 
Abdullah Ahmad Badawi (2006). Ucapan Perdana Menteri Malaysia semasa membentangkan usul mengenai Rancangan Malaysia ke 9, 2006-2010 di Dewan Rakyat pada 31 Mac 2006.

Basrur, S. V. (2003). Physical activity and public health: a call to action. Toronto staff report. ritrived from web www.toronto.ca/health at 15 December 2005.

Corbin, C. (2002). Physical activity for everyone: what every physical educator should know about promoting lifelong physical activity. Journal of teaching physical education, 21, 128-144.

Davison, K.K. \& Lawson, C.T. (2006). Do attributes in the physical environment influence children's physical activity? A review literature. International journal of behavioral nutrition and physical activity, 3(19), 1-17.

Fein, A. J., Plotnikoff, R.C., Wild, T.C., \& Spence, J.C. (2004). Perceived environment and physical activity in youth. International Journal of Behavioral Medicine, 11(3), 135-142.

Ferguson, K.J., Yesalis, C.E., Promrehn, P.R., \& Kirkpatrick, M.B. (1989). Attitudes, knowledge, and beliefs as predictors of exercise intent and behavior in school children. Journal of School Health, 69.

Giles-Corti, B. \& Donovan, R.J. (2002). The relative influence of individual, social and physical environment determinants of physical activity. Social Science and Medicine, 54, 1793-1812.

Institut Penyelidikan Pembangunan Belia Malaysia (2006). Indeks Belia Malaysia 2006. Kementerian Belia \& Sukan Malaysia

Kimm, S.Y., Glynn, N.W., Kriski, A.M., Fitzgerald, S.L., Aaron, D.J., Similom S.L., McMahon, R.P. \& Barton, B.A (2000). Longitudinal changes in physical activity in a biracial cohort during adolescence. Medicine and Science in Sports and Exercise 32, 1445-1454.

Luke, A., Philpott, J., Brett, K., Cruz, L., Lun, V., Prasad, N., \& Zetaruk, M. (2004). Physical inactivity in children and adolescents. CASM AdHoc Committee on children's fitness. Clinical journal of sport medicine, 14, 262-266

Malaysian Government, Ninth Malaysian Plan 2006-2010. (2005) Putrajaya, Malaysia: Malaysian Government.

Phongsavan, P., McLean, G., \& Bauman, A. (2007). Gender differences in influences of perceived environmental and psychosocial correlates on recommended level of physical activity among New Zealanders. Psychology of Sport and Exercise, 8 (6), 939-950.

Poulsen, A.A. \& Ziviani, J.M. (2004). Heatlh enhancing physical activity: factors influencing engagement patterns in children. Australian Occupational Therapy Journal, 51, 69-79.

Sallis, J. F., Prochaska, J.J. \& Taylor, W.C. (2000). A review of correlates of physical activity of children and adolescents. Medicine and science in sport and exercise, 32, 963-975.

Van Mechelen, W.J., Twisk, W.R., Post, G.B., Snel, J. \& Kemper, H.C.G. (2000). Habitual activity of young people: the Amsterdam Growth and Health study. Medical of science in sports and exercise, 32, 1610-1616.

Veitch, J., Bagley, S., Ball, K., \& Salmon, J. (2006). Where do children usually play? A qualitative study of parents' perceptions of influences on children's active free-play. Health and Place, 12, 383-393.

Wilson, N.C. (2008) Pilot Study Report for Survey of Physical Activity \& Sport in Malaysian Children (KAFS08). ISN: Kuala Lumpur, Malaysia. 
Wagner, N \& Kirch, W. (2006). Recommendations for the promotion on physical activity in children. Journal of Public Health, 14, 71-75.

Wu, Tsu-Yin \& Jwo, Jun-Ling (2005). A prospective study on changes of cognitions, interpersonal influences, and physical activity in Taiwanese youth. Research quarterly for Exercise and Sport, 76 (1), 1-10.

Zaini Arshad (2003). Sukan massa sebagai mekanisma pembangunaan komuniti: satu kajian kes mengenai pemahaman \& pendekatan. Unpublished thesis. Universiti Putra Malaysia.

Zainun Ishak \& Aini Hassan (1993). Satu kajian tentang penglibatan pelajar tingkatan IV di Malaysia dalam aktiviti rekreasi (The study about participation among Malaysian secondary students in recreation activities). Jurnal Pendidikan, 18. UKM. 